\begin{tabular}{|l|l|l|}
\hline \multicolumn{2}{|c|}{ PublisherInfo } \\
\hline \hline PublisherName & $:$ & BioMed Central \\
\hline \hline PublisherLocation & $:$ & London \\
\hline \hline PublisherImprintName & $:$ & BioMed Central \\
\hline \hline
\end{tabular}

\title{
Immunomodulation by statins
}

\begin{tabular}{|l|l|l||}
\hline \multicolumn{2}{|c|}{ ArticleInfo } \\
\hline \hline ArticleID & $:$ & 126 \\
\hline \hline ArticleDOI & $:$ & $10.1186 /$ ar-2000-66870 \\
\hline \hline ArticleCitationID & $:$ & 66870 \\
\hline \hline ArticleSequenceNumber & $:$ & 83 \\
\hline \hline ArticleCategory & $:$ & Paper Report \\
\hline \hline ArticleFirstPage & $:$ & 1 \\
\hline \hline ArticleLastPage & $:$ & 3 \\
\hline \hline & & RegistrationDate : 2000-12-21 \\
ArticleHistory & $:$ & OnlineDate $\quad$ 2000-12-21 \\
\hline \hline ArticleCopyright & $:$ & Current Science Ltd2000 \\
\hline \hline ArticleGrants & $:$ & \\
\hline \hline ArticleContext & $:$ & 130753311 \\
\hline \hline
\end{tabular}




\section{Keywords}

CIITA, MHC-II, statin, T-lymphocyte activation

\section{Context}

Statins inhibit an important regulatory step in cholesterol biosynthesis that results in the reduction of circulating cholesterol levels. Treatment with statins, therefore, considerably reduces the risk of coronary heart disease. In addition to their lipid-lowering effects, statins have also been identified as having antioxidant, anti-inflammatory and angiogenic properties. In order to investigate whether statins may modulate immune responses, the authors studied the effect of a variety of statins on interferon (IFN)-?-inducible major histocompatability complex class II (MHC-II) expression and subsequent lymphocyte activation.

\section{Significant findings}

Flow cytometric and immunofluorescent analyses demonstrated that atorvastatin, lovastatin or pravastatin inhibit IFN-?-induced MHC-II protein expression on endothelial cells and macrophages. MHC-I expression and constitutive MHC-II expression were unaffected. Mixed lymphocyte experiments confirmed that inhibition of MHC-II expression gave rise to reduced T lymphocyte activation. RNase protection assays demonstrated that the inhibition of IFN-?-induced MHC-II mRNA expression by statins is paralleled by a reduction in the transactivator CIITA. CIITA promoter IV is specifically responsible for the IFN-?-inducible expression of CIITA, and its expression decreased following treatment with statins. Therefore, in conclusion, statins repress IFN-?-inducible MHC-II expression by inhibiting promoter IV of the MHC-II transactivator CIITA.

\section{Comments}

This simple and elegant study demonstrates that statins, a family of lipid-lowering drugs, can repress MHC-II expression and subsequent T cell activation. Statins are predominantly used in the treatment of 
hypercholesterolemia and in the primary and secondary prevention of coronary heart disease. However, this in vitro study points to a potential therapeutic role for statins as immunosuppressive agents in the treatment of chronic inflammatory conditions. Firstly however, the in vivo relevance of this finding must be established. Further investigation is also required to establish the precise mechanism of inhibition: whether it is dependent on the lipid-lowering properties of statins, or as a result of alteration in the levels of intermediates of the cholesterol biosynthetic pathway.

\section{Methods}

FACS, immunofluorescence, RNase protection assays, tritiated thymidine incorporation, western blotting

\section{References}

1. Kwak B, Mulhaupt F, Myit S, Mach F: Statins as a newly recognized type of immunomodulator. Nat Med. 2000, 6: 1399-1402.

This PDF file was created after publication. 